\title{
Expression of tumor necrosis factor alpha, interleukin-1 and matrix metalloproteinase- 9 and pathomorphological changes in acquired middle ear cholesteatoma
}

\section{Dalibor Vranješ',2, Predrag Špirić, ${ }^{1,2}$ Mirjana Gnjatić, ${ }^{1,2}$}

\author{
'University of Banja Luka, \\ Faculty of Medicine, Banja Luka, \\ The Republic of Srpska, \\ Bosnia and Herzegovina \\ ${ }^{2}$ University Clinical Center of the \\ Republic of Srpska, Ear, Nose and \\ Throat Department, \\ Banja Luka, The Republic of \\ Srpska, Bosnia and Herzegovina
}

Received: 26/04/2021

Accepted: 31/05/2021

\section{Corresponding author: \\ Dalibor Vranješ, PhD, MD \\ 12 beba bb, 78000 Banja Luka, Bosnia and Herzegovina dalibor.vranjes@yahoo.com}

Copyright: @2021 Dalibor Vranješ et all. This is an Open Access article distributed under the terms of the Creative Commons Attribution 4.0 International (CC BY 4.0) license.

\section{Summary \\ Introduction. The inflammatory mediators play a central role in the pathogenesis of the inflammatory process of the middle ear and cho- lesteatoma from the aspect of initiating and maintaining the inflam- matory response to infection and lesion. The aim of the study was to examine if the presence of acquired cholesteatoma could predict path- omorphological changes of the tympanic cavity mucosa in relation to the control tissue of the inflamed middle ear mucosa and to examine and compare the expression levels of tumor necrosis factor-alpha (TNF-a), interleukin-1 (IL-1) and matrix metalloproteinase 9 (MMP-9) with pathomorphological changes in the middle ear mucosa in chron- ic otitis media (COM), with and without acquired cholesteatoma (AC).}

Methods. The immunohistochemical study included 178 patients of both sexes, aged 5 to 75 , who underwent microsurgical treatment of COM from 2015 to 2018. Patients were divided into two groups based on the presence or absence of $A C$ of the middle ear: 97 with cholesteatoma (CCOM) and 81 without cholesteatoma (COM). Samples of the perimatrix of $A C$ and inflamed middle ear mucosa were taken intraoperatively. The condition of the tympanic cavity mucosa was examined by otomicroscopy exploration intraoperatively. The expression levels of TNF- $a$, IL-1 and MMP-9 were determined by immunohistochemical analysis.

Results. The difference in the percentage distribution of patients according to the condition of the tympanic cavity mucosa between both groups was statistically significant $(p<0.01)$ where in the COM group the highest frequency was $43.2 \%$ of patients with mucosal hypertrophy, and in the CCOM $56.7 \%$ with granulations. With highly positive expression of TNF-R2 and IL-1, a higher probability of the presence of mucosal hypertrophy and granulations can be expected, and with highly positive expression of MMP-9 the presence of granulations.

Conclusion. Acquired middle ear cholesteatoma is a statistically significant predictor of the occurence of mucosal hypertrophy and granulations in the tympanic cavity in relation to the control tissue of the inflamed middle ear mucosa. The high expression of TNF-R2, IL-1 and MMP-9 shows a statistically significant association with the presence of granulations and mucosal hypertrophy in acquired middle ear cholesteatoma which may have clinical significance in the evaluation and prognosis of the disease.

Keywords: cholesteatoma, inflammatory mediators, middle ear mucosa 


\section{Introduction}

Cholesteatoma is defined as a cystic, expansive lesion of the temporal bone, consisting of a multilayered squamous epithelium with desquamated keratin, whose main feature is characterized by progressive growth with destruction of the surrounding bone due to the pressure effect and activation of the osteoclasts. Cholesteatoma may be classified as either congenital or acquired [1,2]. The development of acquired cholesteatoma is characterized by a cascade of reactions at the molecular level, which include the induction of MMP, the release of oxygen radicals and other inflammatory mediators, leading to the destructive effects of cholesteatoma, based on proteolytic activity, bone resorption and recruitment of inflammatory cells [3].

The inflammatory mediators have a leading role in the pathogenesis of the inflammatory process of acquired middle ear cholesteatoma from the aspect of initiating and maintaining the inflammatory response to infection and lesion. They may be one of the reasons why in some patients there is a progression from the acute to the chronic phase of the inflammatory process of the middle ear, as well as the development of cholesteatoma [4-6]. In most cases, in the induction of the development of cholesteatoma, disorders of internal molecular regulation participate together with external stimuli in the form of proinflammatory cytokines, growth factors and/or bacterial toxins. The pathogenetic reason for the uncontrolled proliferation of cholesteatoma tissue has not been fully clarified until now $[7,8]$.

The main physiological effect of TNF- $\alpha$, as one of the major inflammatory cytokines, is to promote the immune and inflammatory response of recruited neutrophils and monocytes at the site of infection with their concomitant activation, resulting in its numerous effects in the body [9]. The correlation of the levels of TNF- $\alpha$ expression in the tissue of acquired cholesteatoma with the level of inflammation has been proven. However, precise mechanisms in the process of their action are still the subject of scientific research [10].

Interleukin- 1 cytokines (IL- $1 \alpha$, IL-1 $\beta$ and IL-1Ra) have a significant role in immune regulation and inflammatory processes by inducing the expression of many effector proteins, such as cytokines/chemokines, nitric oxide synthases and matrix metalloproteinase [11]. Cholesteatoma epithelial cells and inflammatory cells of the tissue of the surrounding granulations can produce IL-1. IL- $1 \alpha$ and IL$1 \beta$ levels are significantly higher in cholesteatoma than in normal squamous epithelium. IL-1 is involved in the process of bone resorption, and has been shown to stimulate keratinocyte proliferation $[12,13]$.

MMPs belong to the family of zinc metalloenzymes that are secreted as latent proenzymes and activated during proteolytic degradation processes [14]. MMP-9 is produced in a variety of cells, including epithelial cells, fibroblasts, keratinocytes, osteoblasts, dendritic cells, macrophages, granulocytes, and T cells [15]. MMP-9 has a key role in inflammatory cell migration and destructive behavior of cholesteatoma although serum MMP-9 levels do not necessarily directly reflect the extent of local tissue inflammation [16].

The aim of the study was to examine if the presence of acquired cholesteatoma could predict pathomorphological changes of the tympanic cavity mucosa in relation to the control tissue of the inflamed middle ear mucosa and to examine and compare the expression levels of tumor necrosis factor-alpha (TNF- $\alpha$ ), interleukin-1 (IL-1) and matrix metalloproteinase 9 (MMP-9) with pathomorphological changes in the middle ear mucosa in chronic otitis media (COM), with and without acquired cholesteatoma (AC). 


\section{Methods}

The immunohistochemical study included 178 patients of both sexes, aged 5 to 75 , who underwent microsurgical treatment of COM at the Ear, Nose and Throat Department, University Clinical Center of the RS (UCC RS), Banja Luka, from 2015 to 2018. The study was approved by the Ethics Committee of the UCC RS. Patients were divided into two groups based on the presence or absence of AC: 97 with cholesteatoma (CCOM) and 81 without cholesteatoma (COM). The diagnosis of the disease is based on the history of the disease, clinical examination of the patients and additional diagnostic procedures. Closed and open tympanoplasty techniques with modifications were applied. Samples of the perimatrix of AC $(\mathrm{n}=97)(\mathrm{CCOM})$ and inflamed mucosa $(\mathrm{n}=81)$ $(\mathrm{COM})$ of the middle ear were taken from the patients during the microsurgical procedure. The condition of the tympanic cavity mucosa was examined by otomicroscopy exploration intraoperatively, which is classified into the following categories: eutrophy, hypertrophy, granulations and polypoid altered mucosa.

The patients with diagnosed COM with and without $\mathrm{AC}$, who were referred for middle ear surgery, were included. The patients with congenital cholesteatoma, malignant tumor of the middle ear, otitis externa, previous history of ear surgery, as well as samples of cholesteatoma without perimatrix, were excluded from the study. Samples obtained during the microsurgical procedure were fixed in $10 \%$ formalin and then molded into paraffin blocks from which $4 \mu \mathrm{m}$ thick semester sections were obtained. After dewaxing, the samples were stained by routine hematoxylin-eosin method and then analyzed under a light microscope. Samples were treated with citrate buffer by heating in a microwave oven for 20 minutes to unmask the antigen. After blocking endogenous peroxidase with hydrogen peroxide in methanol, the samples were washed in tris-buffered saline solution with
$\mathrm{pH}$ of 7.6

For the immunohistochemistry analysis of TNF- $\alpha$ (TNF-R2 ) and IL-1, Rabbit TNF-R2 Polyclonal Antibody (TNFR2 Polyclonal Antibody, Product\#PA1-21148, Thermo Fisher, USA) and IL-1 alpha Polyclonal Antibody (IL1 alpha Polyclonal Antibody, Product\# PA525921, Invitrogen, Thermo Fisher, USA) were used, and for the analysis of MMP-9, Mouse anti-MMP-9 Monoclonal Antibody (MMP9 Monoclonal Antibody, Clone 2C3, Product \# MA1-12894, Invitrogen, Thermo Fisher, USA). Immunohistochemical identification of the examined mediators was performed using the EnVision technique. 3,3'-Diaminobenzidine was used as the chromogenic substrate, while contrast was performed with hematoxylin. Imunohistochemistry analysis was performed manually in the competent laboratory of the Department of Clinical Pathology. Original reagents were used.

In immunohistochemically processed samples, expression intensities were observed in each individual sample, while the analysis of immunohistochemical reactions was based on quantitative (0 - absent, 1 - present) and semiquantitative determination of expression intensity by light microscope with a grading scale from 0 to 3 ( 0 - absent, 1 - weak, 2 - moderate, 3 - high intensity).

In relation to the percentage of stained cells, it was divided into 4 categories. Results were considered negative if there was no staining and were marked with 0 , weakly positive in $\leq 25 \%$ of positive cells with label 1 , moderately positive in $\geq 25-50 \%$ of positive cells with label 2 , and highly positive with label 3 , if $\geq 50 \%$ of positive cells were present. Determination of the total result of the immunohistochemical reaction was calculated based on the product of the results of the expression intensity and the percentage of stained cells. The overall results of the analysis were considered negative in $\mathrm{R} \leq 1$ and were marked with 0 , weakly positive in $R \geq 2 \leq 3$ with a notation of $1+$, moderately positive in $R \geq 4 \leq 6$ with a notation of $2+$, and very 
positive in $\mathrm{R}=9$ with the notation $3+$.

The data were analyzed at the level of descriptive statistics, by calculating the absolute and relative distributions of COM and CCOM patients, with mediator expression levels, in relation to the observed factors, and by calculating the arithmetic mean and standard deviation for patient age. For the purpose of calculating the difference in the distribution of the patients of the COM and CCOM groups, the Pearson $\chi^{2}$-test was used, and Mann-Whitney U - the nonparametric test was used for calculating the differences in the age of the subjects between the groups. Categorical logistic regression was performed to evaluate the influence of the two variables: presence or absence of the cholesteatoma (CCOM/COM) and the level of TNF R2, $\mathrm{IL}-1$ and MMP-9 expression respectively on the occurrence probability of the tympanic cavity mucosa pathological changes. The results are considered significant if $p<0.05$. Statistical data processing was performed using SPSS version 21.0 data processing tools (IBM, USA).

\section{Results}

Out of the total of 151 (84.8\%) patients with pathologically altered tympanic cavity mucosa, the highest frequency was shown by $76(42.7 \%)$ patients with granulations and 67 $(37.6 \%)$ with mucosal hypertrophy. The dif- ference in the percentage distribution of patients according to the condition of the tympanic cavity mucosa between both groups was statistically significant $(p<0.01)$ where in the COM group the highest frequency was shown by $43.2 \%$ of patients with mucosal hypertrophy, and in the CCOM by $56.7 \%$ of patients with granulations (Table 1).

The results of the levels of the TNF-R2, IL-1 and MMP-9 expression among the patients classified in two groups based on the cholesteatoma presence and on the tympanic cavity mucosa pathological changes are shown in Tables 2, 3 and 4 respectively.

A categorical logistic regression, which included the CCOM/COM groups and TNF-R2 expression results, showed that both predictors had a statistically significant effect on the occurrence probability of pathologically altered mucosa of the tympanic cavity $(p<0.01)$. This result implies that a higher probability of the mucosal hypertrophy and granulation in the presence of cholesteatoma (CCOM group) and weak $(R=1+)$ and moderately positive $(R$ $=2+$ ) expression of TNF-R2 can be expected (Table 5).

A categorical logistic regression, which included the CCOM/COM groups and IL-1 expression results, showed that both predictors had a statistically significant effect on the occurrence probability of pathologically altered

Table 1. The patients according to the condition of the tympanic cavity mucosa

\begin{tabular}{|c|c|c|c|c|c|}
\hline & & & \multicolumn{2}{|c|}{ Group } & \multirow{2}{*}{ Total } \\
\hline & & & CCOM & COM & \\
\hline \multirow{8}{*}{$\begin{array}{l}\text { The tympanic } \\
\text { cavity mucosa }\end{array}$} & \multirow{2}{*}{ Eutrophic } & $\mathrm{N}$ & 3 & 24 & 27 \\
\hline & & $\%$ & $3.1 \%$ & $29.6 \%$ & $15.2 \%$ \\
\hline & \multirow{2}{*}{ Hypertrophic } & $\mathrm{N}$ & 32 & 35 & 67 \\
\hline & & $\%$ & $33.0 \%$ & $43.2 \%$ & $37.6 \%$ \\
\hline & \multirow{2}{*}{ Granulations } & $\mathrm{N}$ & 55 & 21 & 76 \\
\hline & & $\%$ & $56.7 \%$ & $25.9 \%$ & $42.7 \%$ \\
\hline & \multirow{2}{*}{ Polypoid modified } & $\mathrm{N}$ & 7 & 1 & 8 \\
\hline & & $\%$ & $7.2 \%$ & $1.2 \%$ & $4.5 \%$ \\
\hline \multirow{2}{*}{ Total } & & $\mathrm{N}$ & 97 & 81 & 178 \\
\hline & & $\%$ & $100.0 \%$ & $100.0 \%$ & $100.0 \%$ \\
\hline
\end{tabular}

Chi-square test: $\gamma^{2}=35.23, p=0,000 ; p<0.01$ 
Table 2. Different levels of the TNF-R2 expression among the patients classified in two groups based on the cholesteatoma presence and on the tympanic cavity mucosa pathological changes in every group

\begin{tabular}{|c|c|c|c|c|c|c|}
\hline \multirow{3}{*}{$\begin{array}{l}\text { Inflammatory } \\
\text { mediator }\end{array}$} & \multirow{3}{*}{ Group } & \multirow{3}{*}{$\begin{array}{c}\text { Level of } \\
\text { expression }\end{array}$} & \multicolumn{4}{|c|}{ Tympanic cavity mucosa } \\
\hline & & & Eutrophic & Hypertrophic & Granulations & $\begin{array}{c}\text { Polypoid } \\
\text { altered }\end{array}$ \\
\hline & & & $\mathbf{N}(\%)$ & $\mathbf{N}(\%)$ & N (\%) & N (\%) \\
\hline \multirow{8}{*}{ TNF-R2 } & \multirow{4}{*}{$\mathrm{CCOM}$} & $\mathrm{R}=0$ & $1(8.3 \%)$ & $3(25.0 \%)$ & $8(66.7 \%)$ & $0(0.0 \%)$ \\
\hline & & $\mathrm{R}=1+$ & $1(5.9 \%)$ & $6(35.3 \%)$ & $9(52.9 \%)$ & $1(5.9 \%)$ \\
\hline & & $\mathrm{R}=2+$ & $0(0.0 \%)$ & $17(41.5 \%)$ & $22(53.7 \%)$ & $2(4.9 \%)$ \\
\hline & & $\mathrm{R}=3+$ & $1(3.7 \%)$ & $6(22.2 \%)$ & $16(59.3 \%)$ & $4(14.8 \%)$ \\
\hline & \multirow{4}{*}{$\mathrm{COM}$} & $\mathrm{R}=0$ & $4(57.1 \%)$ & $3(42.9 \%)$ & $0(0.0 \%)$ & $0(0.0 \%)$ \\
\hline & & $\mathrm{R}=1+$ & $9(31.0 \%)$ & $14(48.3 \%)$ & $6(20.7 \%)$ & $0(0.0 \%)$ \\
\hline & & $\mathrm{R}=2+$ & $10(25.6 \%)$ & $15(38.5 \%)$ & $14(35.9 \%)$ & $0(0.0 \%)$ \\
\hline & & $\mathrm{R}=3+$ & $1(16.7 \%)$ & $3(50.0 \%)$ & $1(16.7 \%)$ & $1(16.7 \%)$ \\
\hline
\end{tabular}

CCOM - chronic otitis media with cholesteatoma, COM - chronic otitis media, TNF-R2 - tumor necrosis alpha receptor, $R=$ 0 - negative result; $R=1+$ - weakly positive result; $R=2+$ - moderately positive result; $R=3+$ - very positive result

Table 3. Different levels of the IL-1 expression among the patients classified in two groups based on the cholesteatoma presence and on the tympanic cavity mucosa pathological changes in every group

\begin{tabular}{|c|c|c|c|c|c|c|}
\hline \multirow{3}{*}{$\begin{array}{l}\text { Inflammatory } \\
\text { mediator }\end{array}$} & \multirow{3}{*}{ Group } & \multirow{3}{*}{$\begin{array}{c}\text { Level of } \\
\text { expression }\end{array}$} & \multicolumn{4}{|c|}{ Tympanic cavity mucosa } \\
\hline & & & Eutrophic & Hypertrophic & Granulations & $\begin{array}{c}\text { Polypoid } \\
\text { altered }\end{array}$ \\
\hline & & & N (\%) & $\mathbf{N}(\%)$ & $\mathbf{N}(\%)$ & $\mathbf{N}(\%)$ \\
\hline \multirow{8}{*}{ IL-1 } & \multirow{4}{*}{ CCOM } & $\mathrm{R}=0$ & $0(0.0 \%)$ & $4(33.3 \%)$ & $8(66.7 \%)$ & $0(0.0 \%)$ \\
\hline & & $\mathrm{R}=1+$ & $1(9.1 \%)$ & $4(36.4 \%)$ & $6(54.5 \%)$ & $0(0.0 \%)$ \\
\hline & & $\mathrm{R}=2+$ & $1(2.8 \%)$ & $11(30.6 \%)$ & $22(61.1 \%)$ & $2(5.6 \%)$ \\
\hline & & $\mathrm{R}=3+$ & $1(2.6 \%)$ & $13(34.2 \%)$ & $19(50.0 \%)$ & $5(13.2 \%)$ \\
\hline & \multirow{4}{*}{$\mathrm{COM}$} & $\mathrm{R}=0$ & $1(100.0 \%)$ & $0(0.0 \%)$ & $0(0.0 \%)$ & $0(0.0 \%)$ \\
\hline & & $\mathrm{R}=1+$ & $5(71.4 \%)$ & $2(28.6 \%)$ & $0(0.0 \%)$ & $0(0.0 \%)$ \\
\hline & & $\mathrm{R}=2+$ & $7(25.0 \%)$ & $19(67.9 \%)$ & $2(7.1 \%)$ & $0(0.0 \%)$ \\
\hline & & $\mathrm{R}=3+$ & $11(24.4 \%)$ & $14(31.1 \%)$ & $19(42.2 \%)$ & $1(2.2 \%)$ \\
\hline
\end{tabular}

CCOM - chronic otitis media with cholesteatoma, COM - chronic otitis media, IL-1 - interleukin -1, $R=0$ - negative result; $R=1+$ weakly positive result; $R=2+$ - moderately positive result; $R=3+$ - very positive result

mucosa of the tympanic cavity $(\mathrm{p}<0.01)$. This result implies that a higher probability of the mucosal hypertrophy and granulation in the presence of cholesteatoma (CCOM group) and moderately $(R=2+)$ and very positive $(R=3$ + ) expression of IL-1can be expected (Table 6).

A categorical logistic regression, which included CCOM/COM groups and MMP-9 expression results, showed that both predictors had a statistically significant effect on the occurrence probability of the pathologically altered tympanic cavity mucosa $(\mathrm{p}<0.01)$. This result implies that a higher probability of mucosal hypertrophy and granulation can be expected in the presence of cholesteatoma (CCOM group) and very positive $(\mathrm{R}=3+)$ expression of MMP-9. With moderately positive $(\mathrm{R}=2+)$ expression of MMP-9, a higher probability of the presence of granulations can be expected (Table 7). 
Table 4. Different levels of the MMP-9 expression among the patients classified in two groups based on the cholesteatoma presence and on the tympanic cavity mucosa pathological changes in every group

\begin{tabular}{|c|c|c|c|c|c|c|}
\hline \multirow{3}{*}{$\begin{array}{l}\text { Inflammatory } \\
\text { mediator }\end{array}$} & \multirow{3}{*}{ Group } & \multirow{3}{*}{$\begin{array}{l}\text { Level of } \\
\text { expression }\end{array}$} & \multicolumn{4}{|c|}{ Tympanic cavity mucosa } \\
\hline & & & Eutrophic & Hypertrophic & Granulations & $\begin{array}{c}\text { Polypoid } \\
\text { altered }\end{array}$ \\
\hline & & & $\mathbf{N}(\%)$ & N (\%) & N (\%) & N (\%) \\
\hline \multirow{8}{*}{ MMP-9 } & \multirow{4}{*}{ CCOM } & $\mathrm{R}=0$ & $0(0.0 \%)$ & $0(0.0 \%)$ & $1(50.0 \%)$ & $1(50.0 \%)$ \\
\hline & & $\mathrm{R}=1+$ & $1(3.7 \%)$ & $12(44.4 \%)$ & $12(44.4 \%)$ & $2(7.4 \%)$ \\
\hline & & $\mathrm{R}=2+$ & $0(0.0 \%)$ & $10(27.8 \%)$ & $23(63.9 \%)$ & $3(8.3 \%)$ \\
\hline & & $R=3+$ & $2(6.3 \%)$ & $10(31.3 \%)$ & $19(59.4 \%)$ & $1(3.1 \%)$ \\
\hline & \multirow{4}{*}{$\mathrm{COM}$} & $\mathrm{R}=0$ & $17(43.6 \%)$ & $18(46.2 \%)$ & $4(10.3 \%)$ & $0(0.0 \%)$ \\
\hline & & $\mathrm{R}=1+$ & $5(19.2 \%)$ & $13(50.0 \%)$ & $8(30.8 \%)$ & $0(0.0 \%)$ \\
\hline & & $\mathrm{R}=2+$ & $2(14.3 \%)$ & $4(28.6 \%)$ & $8(57.1 \%)$ & $0(0.0 \%)$ \\
\hline & & $\mathrm{R}=3+$ & $0(0.0 \%)$ & $0(0.0 \%)$ & $1(50.0 \%)$ & $1(50.0 \%)$ \\
\hline
\end{tabular}

CCOM - chronic otitis media with cholesteatoma, COM - chronic otitis media, MMP-9 - metalloproteinase matrix $9, R=0$ - negative result; $R=1+$ - weakly positive result; $R=2+$ - moderately positive result; $R=3+$ - very positive result

Table 5. The influence of the presence/absence of the cholesteatoma and the level of TNF-R2 expression on the tympanic cavity mucosa pathological changes

\begin{tabular}{ccccccc}
\hline \multirow{2}{*}{ Variables } & \multicolumn{2}{c}{$\begin{array}{c}\text { Standard } \\
\text { coefficients }\end{array}$} & & df & $\mathbf{F}$ & $\mathbf{p}$ \\
\cline { 2 - 3 } & Beta & S.E. & & & \\
\hline $\begin{array}{c}\text { CCOM/ } \\
\text { COM }\end{array}$ & -.414 & .073 & 2 & 32.195 & $.000^{* *}$ \\
\hline TNF-R2 & .173 & .076 & 4 & 5.229 & $.001^{* *}$ \\
\hline
\end{tabular}

** $p<0.01$, CCOM - chronic otitis media with cholesteatoma, COM - chronic otitis media without cholesteatoma, TNF-R2 - tumor necrosis alpha receptor, Beta - standard partial regression coefficient; S.E. - standard regression error; $d f$ - number of degrees of freedom; $F$ - variance ratio test; Dependent variable: the tympanic cavity mucosa pathological changes
Table 6. The influence of the presence/absence of the cholesteatoma and the level of IL-1 expression on the tympanic cavity mucosa pathological changes

\begin{tabular}{|c|c|c|c|c|c|}
\hline \multirow{2}{*}{ Variables } & \multicolumn{2}{|c|}{$\begin{array}{c}\text { Standard } \\
\text { coefficients }\end{array}$} & \multirow{2}{*}{ df } & \multirow[t]{2}{*}{ F } & \multirow{2}{*}{ p } \\
\hline & Beta & S.E. & & & \\
\hline $\begin{array}{l}\text { CCOM/ } \\
\text { COM }\end{array}$ & -.473 & .059 & 1 & 64.357 & $.000^{* *}$ \\
\hline IL-1 & .222 & .065 & 3 & 11.705 & $.000^{* *}$ \\
\hline
\end{tabular}

** $p<0.01$, CCOM - chronic otitis media with cholesteatoma, COM - chronic otitis media without cholesteatoma, TNF-R2 - tumor necrosis alpha receptor, IL-1 - interleukin -1, Beta-standard partial regression coefficient; S.E. - standard regression error; $d f$ - number of degrees of freedom; $F$ - variance ratio test; Dependent variable: the tympanic cavity mucosa pathological changes

Table 7. The influence of the presence/absence of the cholesteatoma and the level of MMP-9 expression on the tympanic cavity mucosa pathological changes

\begin{tabular}{|c|c|c|c|c|c|}
\hline \multirow{2}{*}{ Variables } & \multicolumn{2}{|c|}{ Standard coefficients } & \multirow{2}{*}{ df } & \multirow{2}{*}{$\mathbf{F}$} & \multirow{2}{*}{$\mathrm{p}$} \\
\hline & Beta & S.E. & & & \\
\hline $\mathrm{CCOM} / \mathrm{COM}$ & -.386 & .091 & 1 & 18.028 & $.000^{* *}$ \\
\hline MMP-9 & .333 & .116 & 3 & 8.296 & $.000^{* *}$ \\
\hline
\end{tabular}

** $p<0.01$, CCOM - chronic otitis media with cholesteatoma, COM - chronic otitis media without cholesteatoma, MMP9 - metalloproteinase matrix 9, Beta - standard partial regression coefficient; S.E. - standard regression error; $d f$ - number of degrees of freedom; F-variance ratio test; Dependent variable: the tympanic cavity mucosa pathological changes 


\section{Discussion}

In $151(84.8 \%)$ patients in the total sample, a pathological finding was observed on tympanic cavity mucosa. The difference in the distribution of patients according to the examined pathomorphological change was statistically significant $(\mathrm{p}<0.01)$, where mucosal hypertrophy in the COM group (43.2\%) and granulations in the CCOM group (56.7\%) showed the highest frequency. Highly positive TNF-R2 and IL-1 expression was recorded in both groups, while in terms of MMP-9 results, the highest frequency in the CCOM group was shown by high-positive expression, and in the COM group by negative expression (Figure 1). The predictor model, which included the level of expression of TNF-R2, IL-1 and MMP-9 in relation to cholesteatoma tissue and control tissue of inflamed tympanic cavity mucosa, proved a statistically significant prediction of cholesteatoma presence on pathological changes of tympanic cavity mucosa, respectively the occurrence of mucosal hypertrophy and granulations. There was also a statistically significantly higher probability of the presence of granulationss in the highly positive TNF-R2, IL-1 and MMP-9 expression and mucosal hypertrophy in the highly positive TNF-R2 and IL-1 expression. These data corroborate literature data.
Akimoto et al. state that most AC are associated with an inflammatory cell infiltrate. The authors find the presence of granulationss in the acquired, in contrast to congenital cholesteatoma, but also a statistically significant correlation of TNF- $\alpha$ expression levels with the degree of infection and bone resorption, in contrast to IL-1 expression levels. In the same study, no statistically significant correlation was found between the expression levels of TNF- $\alpha$ and IL- 1 and the presence of granulationss in AC [17].

Marenda i Aufdemorte immunolocalized a high levels of TNF- $\alpha$, TGF- $\beta 1$ and 2 , and IL-1 and IL- 6 expression in the epithelial and subepithelial layers of AC of human origin. The autors proved that elevated levels of these inflammatory mediators in the epithelial layer and stroma of AC significantly correlate with the presence of granulation tissue, as well as with degree of erosion of the auditory ossicles and surrounding bone [18].

Kuczkowski et al. found high levels of IL1 , TNF- $\alpha$ and IL- 6 expression in granulations and cholesteatoma tissue. The authors point out that a strong positive association between the levels of these cytokines and the degree of osteolysis of bone indicates the destructive behavior of cholesteatoma or granulation tissue [19]. Sudhoff et al. point out that cholesteatoma epithelium shows a high staining intensity of a)

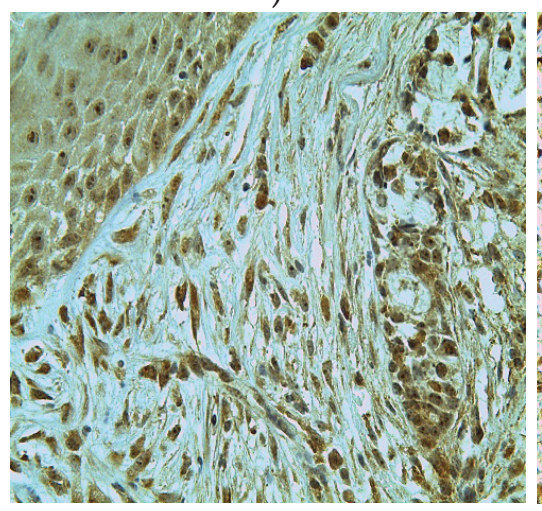

b)

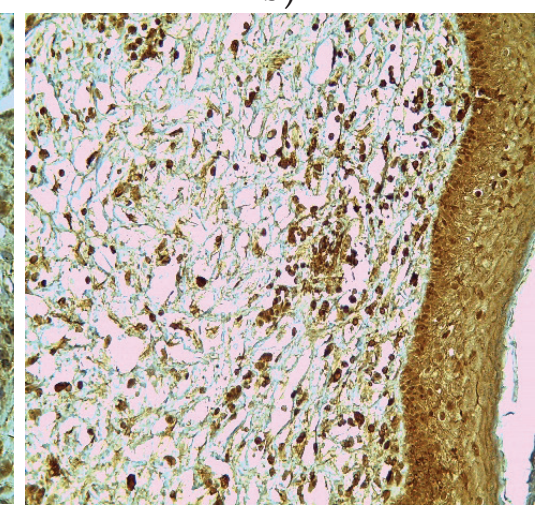

c)

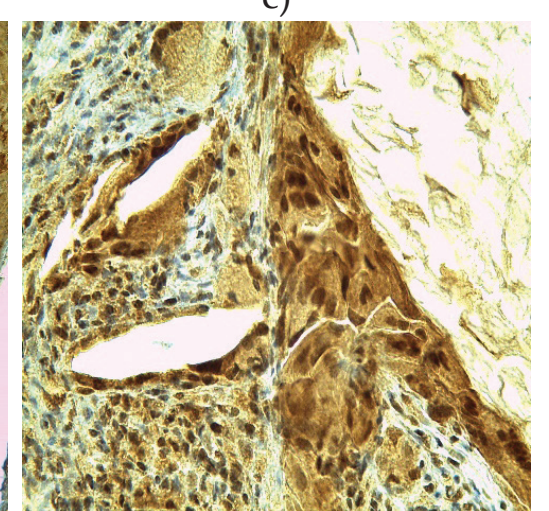

Figure 1. A high expression of stromal and inflammatory cells in environment of cholesteatoma (IHC): anti-TNFR2x400 (a), anti-IL1×400 (b) and anti-MMP9x400 (c) 
IL-1, TGF- $\alpha$, and the epidermal growth factor receptor (EGF-R) in contrast to middle ear mucosa. The authors also found high concentrations of lymphocytes and macrophages in the surrounding stroma of cholesteatoma, most of which expressed IL-1, TGF- $\alpha$ and EGF-R [20]. Yetiser et al. demonstrate that there are no statistical differences in TNF- $\alpha$ and IL-1 expression levels between granulations and external auditory canal skin tissue, while Kim et al. in their study found significantly higher levels of IL-1 mRNA expression in granulations versus healthy skin tissue and cholesteatoma [21,22]. Schmidt et al. point out that MMP-9 expression occurs mainly in the suprabasal, and less frequently in the basal layers of the cholesteatoma epithelium, as well as in inflammatory cells of the perimatrix, in contrast to keratinocytes and granulation tissue [23]. Schönermark et al. found the expression of MMP-9 and MMP-2, limited only to the basal and suprabasal epithelial cell layers of the cholesteatoma as opposed to the mucosal layer of the tympanic cavity and the tympanic membrane. The autors point out that members of the MMPs family could have an active role in the molecular mechanisms of cholesteatoma invasion of the temporal bone, wich provides new insights into the pathophysiology of the disease and potential therapeutic approaches [24].

\section{Conclusion}

Acquired middle ear cholesteatoma is a statistically significant predictor of the mucosal hypertrophy and granulations occurrence in the tympanic cavity in relation to the control tissue of the inflamed middle ear mucosa. The high expression of TNF-R2, IL-1 and MMP-9 shows a statistically significant association with the presence of granulationss and mucosal hypertrophy in acquired middle ear cholesteatoma which may have clinical significance in the evaluation and prognosis of the disease.
Founding source. A study was derived from the scientific-research project: "Significance of expression of the inflammatory mediators in middle ear cholesteatoma", supported from the Ministry for Scientific and Technological Development, Higher Education and Information Society of the Republic of Srpska (No. 19/6-020/961-68/15).

\section{References:}

1. Meyer TA, Strunk Jr CL, Lambert PR. Cholesteatoma. In: Bailey BJ, Johnson JT, Newlands SD, eds. Head and Neck surgery - Otolaryngology, 4th edn. Lippincott Williams and Wilkins; 2006. p. 2083-91.

2. Semaan MT, Megerian CA. The pathophysiology of cholesteatoma. Otolaryngol Clin North Am 2006;39(6):1143-59.
Ethical approval. The Ethics Committee of the University of Banja Luka, Faculty of Medicine, approved the study and informed consent was obtained from all the individual respondents. The research was conducted according to the Declaration of Helsinki.

Conflicts of interest. The authors declare no conflicts of interest.

3. Cholesteatoma, an Overview Source: Grand Rounds Presentation Department of Otolaryngology - Head and Neck Surgery. The University of Texas Medical Branch (UTMB), [updated 2019, October 23]. Available from: https://www. utmb.edu/ otoref/2010s-grand-rounds. Acessed September 9, 2020. 
4. Dennis RG, Whitmire RN, Jackson RT. Action of inflammatory mediators on middle ear mucosa. A method for measuring permeability and swelling. Arch Otolaryngol 1976;102(7):420-4.

5. Goldie P, Hellstrom S, Idahl LA. Middle ear effusion induced by various inflammatory mediators and neuropeptides. An experimental study in the rat. Acta Otolaryngol 1989;108(3-4):246-52.

6. Boisvert P, Wasserman SI, Schiff M, Ryan AF. Histamine-induced middle ear effusion and mucosal histopathology in the guinea pig. Ann Otol Rhinol Laryngol 1985;94(2 Pt 1):212-6.

7. Juhn SK, Jung MK, Hoffman MD, Drew BR, Preciado DA, Sausen NJ, et al. The role of inflammatory mediators in the pathogenesis of otitis media and sequelae. Clin Exp Otorhinolaryngol 2008;1(3):117-38.

8. Welkoborsky HJ. Current concepts of the pathogenesis of acquired middle ear cholesteatoma. Laryngorhinootologie 2011;90(1):38-48.

9. Abbas AK, Lichtman AH, Pober JS. Citocinas. In: Imunologia celular e molecular. $2^{\underline{a}}$ ed. Rio de Janeiro: Revinter 1998:253-76.

10. Bingham CO. The pathogenesis of rheumatoid arthritis: pivotal citokynes involved in bone degradation and inflammation. J Reumatol Suppl 2002;65:3-9.

11. Dinarello CA. The IL-1 family and inflammatory diseases. Clin Exp Rheumatol 2002;20(5 Suppl 27):S1-13.

12. Nell MJ, Grote JJ. Endotoxin and tumor necrosis factor-alpha in middle ear effusions in relation to upper airway infection. Laryngoscope 1999;109(11):1815-9.

13. Bikhazi P, Ryan AF. Expression of immunoregulatory cytokines during acute and chronic middle ear immune response. Laryngoscope 1995;105(6):629-34.

14. Birkedal-Hansen H. Role of cytokines and inflammatory mediators in tissue destruction. J Periodont Res 1993:28(6 Pt 2):500-10.

15. Nam SI, Kwon TK. Dexamethasone inhibits interleukin-1beta-induced matrix metalloproteinase-9 expression in cochlear cells. Clin Exp Otorhinolaryngol 2014;7(3):175-80.
16. Olszewska E, Matulka M, Mroczko B, Pryczynicz A, Kemona A, Szmitkowski M, et al. Diagnostic value of matrix metalloproteinase 9 and tissue inhibitor of matrix metalloproteinases 1 in cholesteatoma. Histol Histopathol 2016;31(3):307-15.

17. Akimoto R, Pawankar R, Yagi T, Baba S. Acquired and congenital cholesteatoma: determination of tumor necrosis factor-alpha, intercellular adhesion molecule-1, interleukin-1-alpha and lymphocyte functional antigen-1 in the inflammatory process. ORL 2000;62(5):257-65.

18. Marenda SA, Aufdemorte TB. Localization of cytokines in cholesteatoma tissue. Otolaryngol Head Neck Surg 1995;112(3):359-68.

19. Kuczkowski J, Sakowicz-Burkiewicz M, Iżycka-Świeszewska E, Mikaszewski B, Pawełczyk T. Expression of tumor necrosis factor- $\alpha$, interleukin- $1 \alpha$, interleukin- 6 and interleukin-10 in chronic otitis media with bone osteolysis. ORL J Otorhinolaryngol Relat Spec 2011;73(2):93-9.

20. Sudhoff H, Bujía J, Holly A, Kim C, Fisseler-Eckhoff A. Functional characterization of middle ear mucosa residues in cholesteatoma samples. Am J Otol 1994;15(2):217-21.

21. Yetiser S, Satar B, Aydin N. Expression of epidermal growth factor, tumor necrosis factor-alpha, and interleukin-1alpha in chronic otitis media with or without cholesteatoma. Otol Neurotol 2002;23(5):647-52.

22. Kim CS, Lee CH, Chung JW, Kim CD. Interleukin-1 alpha, interleukin-1 beta and interleukin-8 gene expression in human aural cholesteatomas. Acta Otolaryngol 1996;116(2):302-6.

23. Schmidt M, Grünsfelder P, Hoppe F. Induction of matrix metalloproteinases in keratinocytes by cholesteatoma debris and granulation tissue extracts. Eur Arch Otorhinolaryngol 2000;257(8):425-9.

24. Schönermark M, Mester B, Kempf H-G, Bläser J, Tschesche H, Lenarz T. Expression of matrix-metalloproteinases and their inhibitors in human cholesteatomas. Acta Otolaryngol 1996;116(3):451-6. 


\title{
Ekspresija faktora nekroze tumora alfa, interleukina-1 i matriks metaloproteinaze-9 i patomorfološke promjene kod stečenog holesteatoma srednjeg uha
}

\author{
Dalibor Vranješ ${ }^{12}$, , Predrag Špirić ${ }^{1,2}$, Mirjana Gnjatić, ${ }^{12}$ \\ 'Univerzitet u Banjoj Luci, Medicinski fakultet, Banja Luka, Republika Srpska, Bosna i Hercegovina \\ ${ }^{2}$ Univerzitetski klinički centar Republike Srpske, Klinika za bolesti uha, grla i nosa, Banja Luka, \\ Republika Srpska, Bosna i Hercegovina
}

Uvod. Medijatori inflamacije imaju centralnu ulogu u patogenezi upalnog procesa srednjeg uha i holesteatoma sa aspekta pokretanja i održavanja upalnog odgovora na infekciju i leziju. Cilj istraživanja je bio da se ispita da li prisustvo stečenog holesteatoma može da predvidi patomorfološke promjene sluznice kavuma timpani u odnosu na kontrolno tkivo inflamirane sluznice srednjeg uha, te da se ispitaju i uporede nivoi ekspresije faktora nekroze tumora-alfa (TNF-a), interleukina-1 (IL-1) i matriks metaloproteinaze-9 (MMP-9) s patomorfološkim promjenama na sluznici srednjeg uha kod hroničnog otitis media (HOM), sa i bez stečenog holesteatoma (SH).

Metode. Imunohistohemijska studija je uključila 178 ispitanika oba pola, od 5 do 75 godina, koji su podvrgnuti mikrohirurškom liječenju (HOM) od 2015. do 2018. godine. Ispitanici su podijeljeni u dvije grupe na osnovu prisustva ili odsustva stečenog holesteatoma srednjeg uha: 97 s holesteatomom (HHOM); i 81 bez holesteatoma (HOM). Uzorci perimatriksa SH i inflamirane sluznice srednjeg uha su uzeti intraoperativno. Intraoperativnom otomikroskopskom eksploracijom je ispitano stanje sluznice kavuma timpani. Nivoi ekspresije TNF-a, IL-1 i MMP-9 su određeni imunohistohemijskom analizom.

Rezultati. Razlika u procentualnoj distribuciji ispitanika prema stanju sluznice kavuma timpani između obje grupe se pokazala kao statistički značajna $(p<0,01)$ gdje je u HOM grupi najveću učestalost pokazalo 43,2\% ispitanika s hipertrofijom sluznice, a u HHOM 56,7\% s granulacijama. Visokopozitivna ekspresija TNF-R2 i IL-1 je pokazala statistički značajnu povezanost s prisustvom hipertrofične sluznice i granulacija, a visokopozitivna MMP-9 granulacija.

Zaključak. Stečeni holesteatom srednjeg uha je statistički značajan prediktor nastanka hipertrofične sluznice i granulacija u kavumu timpani u odnosu na kontrolno tkivo inflamirane sluznice srednjeg uha. Visoki stepen ekspresije TNF-R2, IL-1 i MMP-9 pokazuje statistički značajnu povezanost s prisustvom granulacija i hipertrofične sluznice kod stečenog holesteatoma srednjeg uha, što može imati klinički značaj u evaluaciji i prognozi bolesti.

Ključne riječi: holesteatom, medijatori inflamacije, sluznica srednjeg uha 